\title{
IDENTIFYING AND ASSESSING THE FACTORS AFFECTING SKILL GAP IN DIGITAL MARKETING IN COMMUNICATION INDUSTRY COMPANIES
}

\author{
Fereshteh Ghotbifar \\ Department of Management, Islamic Azad University, Iran \\ E-mail: fereshtehghotbifar@gmail.com
}

Mohammadreza Marjani Department of Industrial Engineering, Qom University of Technolog,

Iran

E-mail:marjani@qut.ac.ir

Abbas Ramazani Department of Education, Shahid Beheshti University, Iran E-mail: a_ramezani@sbu.ac.ir

Submission: 02/07/2016

Revision: 07/07/2016

Accept: $27 / 07 / 2016$

\section{ABSTRACT}

As far as new communication channels are concerned, there have been extensive developments in communications and marketing in digital era. Today, therefore, companies try to take advantage of digital marketing channels to provide suitable services for customers to improve their satisfaction level. However, this study aimed to identify and assess factors affecting skill gap in digital marketing. This study is a descriptive correlation one. The population consisted of experts in communications industry to identify most important skill gap in digital marketing and factors affecting them; also, managers and specialists of these companies were investigated to determine the role of identified factors in reducing skill gap. Using localized questionnaire and interviewing with ten experts who were selected by Delphi snowball method, the skill gap in marketing and factors affecting them were identified. Also, researcher made questionnaire consisting 32 questions and distributed them among 226 employees to investigate the identified factors role in reducing skill gap in digital marketing. 
The results showed that from four identified factors, some components including operational strategic factors and environmental factors had direct and positive impact on creating skill gap in digital marketing. The environmental factors such as social and cultural conditions, religion, technology, and economy had more proactive impact on skill gap in digital marketing. Also, the results showed that among skill gap in digital marketing of studied companies, the skills (Principles of Communication) and (Predicting Future) had the highest and lowest gap, respectively.

Keywords: Digital Marketing, Skill Gap, Communication Industry

\section{INTRODUCTION}

Moving from information era to technology development-based sustainable competitive advantage era, there are many continuous new opportunities and challenges for industry and academia activists (GROBELNY; MICHALSKI, 2015).

The business communication with social networks and sites such as Facebook and Twitter which are usually used as a valid business tool have created huge revolution in services and products marketing of companies (AKAR et al, 2011).

The widespread use of digital techniques including social networks in marketing process of companies helps significantly their marketing independence. Using them, the product and service providers increasingly communicate with consumers and individual users, receive feedback, and provide custom solutions to their customers (ROYLE; LAING, 2014).

However, the changes in communication channels due to emergence of digital era have affected communications and marketing industries more than any other industry. The speed and complexity of these elements in marketing process differentiates digital era from the past (BUZZARD et al, 2011).

Therefore, it is significantly important to understand the concept of digital marketing. In this regard, Digital Marketing Institute (DMI) refers to digital marketing as the process of using digital technology for integrating, targeting, and measuring deep communication with customers to retain and acquire customers (HAMILL et al, 2010). 
Today, lack of digital marketing skills within acceptable limits in companies which use this digital technique makes a problem in for using digital marketing process in provision of goods and services (ROYLE; LAING, 2014). The digital marketing skills including knowledge, awareness, and capabilities are needed for using digital tools in product and services marketing process of companies (CHAFFEY; PATRON, 2012).

The history of digital marketing application in industries of different countries highlights this fact that among other industries which use digital marketing, the communication industry faces with more gap in digital marketing skills (ROYLE; LAING, 2014).

The research indicates that the communication principles, interaction with customer, predicting future, integration of marketing skills, research, technical knowledge, and monitoring measurement and refinement are the most important skill gap in digital marketing of communication industry (ROYLE; LAING, 2014; MILLER; GLASSNER, 2011).

A closer look at digital marketing processes in communication industry in Iran clearly indicates that the companies face with various skill gap in digital marketing of their product and services. They also face with major challenges in using digital tools in their marketing and sales. However, this is due to lack of digital marketing skills, from knowledge to integration of different skills.

In this regard, it is important to identify factors affecting skill gap in digital marketing of communication industry companies. Clearly, the identification of factors and taking necessary actions to eliminate the skill gap in digital marketing of companies will contribute significantly in marketing process development and increasing of products and services sale.

The literature review indicated that there is little research in this field and this issue should be addressed. Therefore, this study aims to identify the skill gap in digital marketing of communication industry in Iran and determine the factors affecting the creation of skill gap in digital marketing of studied companies. However, the main question is: What are the most affective factors in creating skill gap in digital marketing of communications industry companies in Iran? 


\section{LITERATURE REVIEW}

In a study on skills needed for modern marketing, researchers acknowledged that marketing graduates should have technical skill and knowledge in Internet marketing and customer relationship management (CRM) (SCHLEE; HARICH, 2010)

The literature of digital marketing skill gap shows that there is major shortcoming in this field in communication industry. In their study about SNS application (social networking sites) by companies, there was lack of available scientific study about this subject (MICHEALIDOU; SIAMAGKA, 2011).

There is a serious need for specialized knowledge of digital marketing skills in all industries (DAY, 2011). He focused on compatibility capabilities, ensuring smart future, market research and communication improvement, and investment in media understanding expertise of colleagues which is a way for effective use of digital marketing capabilities.

In a study, researchers found that Facebook, Twitter, and Linked in are some of the most commonly used social media which primarily attract new customers and create new relationships (MICHAEL DOU; SIAMAK, 2011).

There is still a tendency to focus on one-way communication methods by published digital tools; because there is lack of human resources and technical knowledge to take advantage of social media. It is interesting to note that considering current literature on digital marketing skills, there is no clear detail for digital marketing skill gap (JAVINEN et al, 2012).

The use of online social networks such as Facebook and Twitter by charitable organizations, they found that the barriers to using digital marketing in these organizations include lack of resources and lack of social media marketing skills (FENNIMORE; QUINTON, 2013).

In a study on used social media by executives of General Electric, a number of strategic challenges identified that managers deal with to maximize the benefits of social media. They stated that reverse engineering is required, because digital marketing skills are determined by digital employees (DESIRE; NEWTON, 2013). 
INDEPENDENT JOURNAL OF MANAGEMENT \& PRODUCTION (IJM\&P)

http://www.ijmp.jor.br

v. 8, n. 1, January - March 2017

ISSN: 2236-269X

DOI: 10.14807/ijmp.v8i1.507

They also considered the education level of customers as an effective factor in creating skill gap in digital marketing. The environmental factors are effective factors in creation of digital marketing skill gap in communication companies. However, there is no comprehensive study on identifying the most important factors affecting skill gap creation in digital marketing of communication industry companies. Therefore, this needs further studies (FENNEMORE; QUINTON, 2013).

However, the research on digital marketing of marketing and communication companies indicates that there are several gap in their digital marketing which has led to many challenges for them. The communication principles, interaction with customer, predicting future, integration of marketing skills, research, technical knowledge, and monitoring measurement and refinement are the most important skill gap in digital marketing of communication industry (ROYLE; LAING, 2014).

The investigation of skill gap in digital marketing show that several factors affecting the creation of this gap. Royle \& Laing referred to marketing and operational strategic factors role in creation of skill gap in digital marketing.

Then, according to research variables, it was tried to identify most important factors affecting skill gap development in digital marketing of communication industry companies in Iran. Also, a conceptual model was presented for relationships among variables. For this purpose, a localized semi-structured questionnaire which was based on skill gap of digital marketing in foreign countries was used to identify the most important skill gap in digital marketing of communications industry companies in Iran.

This questionnaire was distributed among experts of communication industry. They were asked to express their opinion about existence of such gap in digital marketing process and mention other gap, if any. From presented skill gap, finally, the experts stated that seven digital marketing skill gap have the utmost importance: communication principles, interaction with customer, predicting future, integration of marketing skills, research, technical knowledge, and monitoring measurement and refinement.

Then, it was tired to identify the most important factors affecting digital marketing skill gap creation in communications industry companies in Iran. Using Delphi method, ten executives and experts in communication Industry companies in 
Iran were interviewed. They were asked to determine the most important factors in digital marketing skill gap creation in three phases. In first phase, therefore, the participants identified a number of factors which overlapped; these factors were eliminated. In second phase, they were asked to determine most effective factors in creation of digital marketing skill gap.

The identified factors were used as input for third phase. From the perspective of interviewees, finally, the factors affecting digital marketing skill gap development in communications industry companies in Iran included operational strategic, marketing, environmental, and education level factors. They were presented in conceptual model. Accordingly, the research hypotheses are as follows:

- H1: The operational strategic factors impact on reduction of skill gap in digital marketing.

- H2: The customer education level impact on reduction of skill gap in digital marketing.

- H3: The marketing factors impact on reduction of skill gap in digital marketing.

- H4: The environmental factors impact on reduction of skill gap in digital marketing.

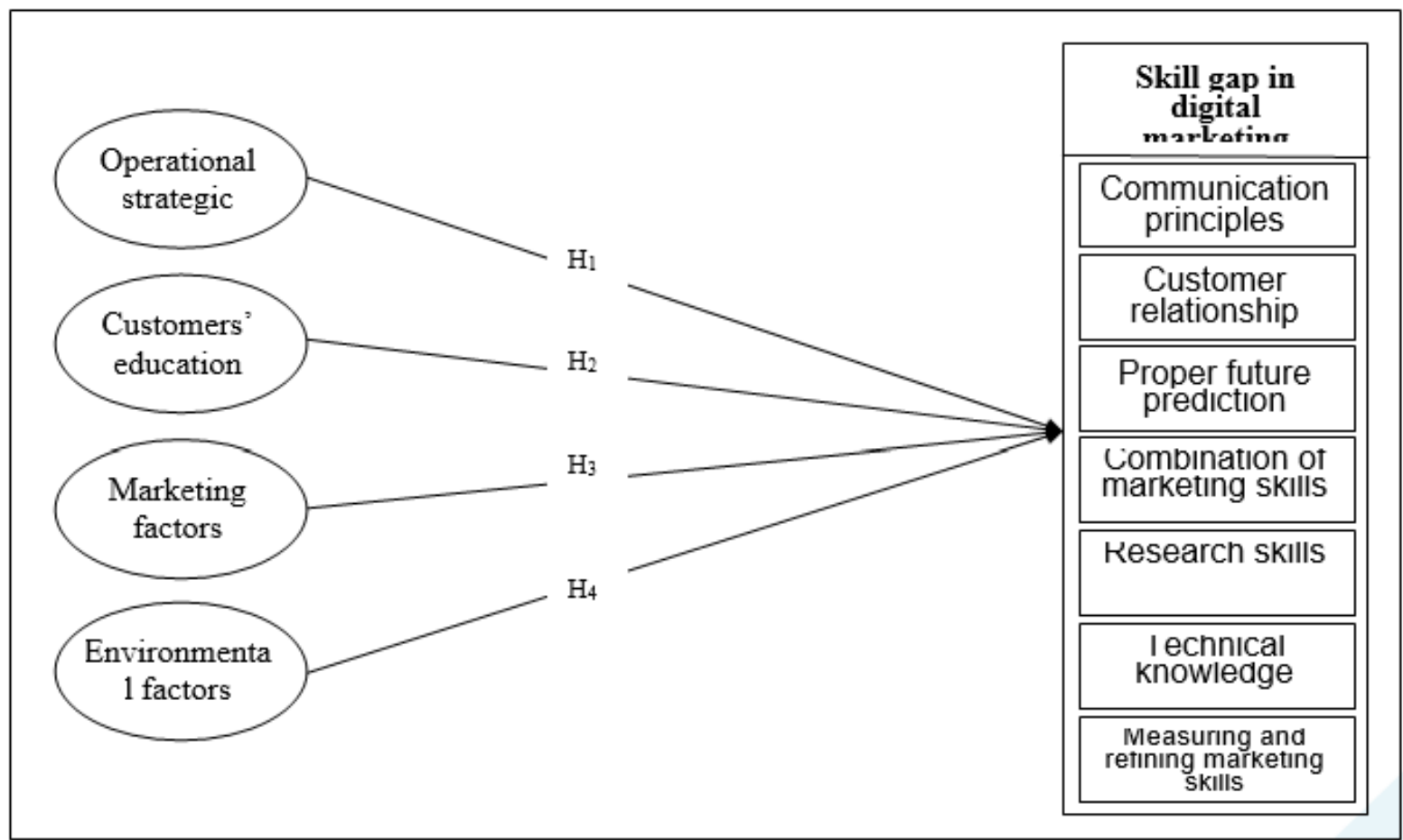

Figure 1: Research conceptual model 
DOI: 10.14807/ijmp.v8i1.507

\section{METHODOLOGY}

This study is a practical combined (qualitative-quantitative) descriptive correlation study. This study had two populations. The first population consisted of managers and experts in communication industry companies in Iran including mobile operators and companies such as Dijikala and Jiring. They were interviewed to identify skill gap in digital marketing and determine most important factors effecting gap creation.

For this purpose, ten experts were selected using snowball method. The data were collected using localized questionnaires and interview based on Delphi method. The second population consisted of all managers and specialists in communication industry companies; according to Administrative Affairs Office of Ministry of Industry, Mine, and Trade, their number was 539 persons.

They were asked to determine the impact of identified factors on digital marketing skill gap in companies. Using Cochran formula and stratified random sampling method, a sample of 226 persons (38 managers and 188 specialists) were selected to answer the questionnaire. In first stage, the data were collected using localized questionnaire and semi-structured interview with ten experts in these companies to identify skill gap in digital marketing and determine the most important factors affecting gap creation in mentioned companies.

In the second stage, a questionnaire with 32 questions which included operational indicators of research variables was used to assess the relationship among variables. It was distributed among samples. Totally, 226 questionnaires were returned.

The content and structure validity of questionnaire was confirmed by specialists and confirmatory factor analysis, respectively. For this purpose, a number of professors and specialists of communication industry companies evaluated the questions and confirmed their content validity. On the other hand, confirmatory factor analysis evaluated the structure validity of variables.

In this regard, the measurement model for each variable was designed in Amos 21 software. Then, the fitness level of models was assessed which shows the measurability of variables by their related questions. The overall fitness indices of measurement models (confirmatory factor analysis and construct validity) are 
presented in Table 1. It can be seen that the measurement models of variables have good fitness and are an appropriate tool to measure variables.

Table 1: Overall indices of measurement models fitness (confirmatory factor analysis)

\begin{tabular}{|r|r|r|r|r|r|r|r|}
\hline Structure/ index & $\mathrm{X}^{2} / \mathrm{df}$ & $\mathrm{P}$ & $\mathrm{RMSEA}$ & $\mathrm{CFI}$ & $\mathrm{CMIN}$ & $\mathrm{RMR}$ & $\mathrm{GFI}$ \\
\hline Acceptable level & $<3$ & $<0 / 05$ & $<0 / 07$ & $>0 / 9$ & --- & $<0 / 05$ & $>0 / 9$ \\
\hline Operational strategic factors & $2 / 882$ & $0 / 000$ & $0 / 052$ & $0 / 965$ & $568 / 88$ & $0 / 034$ & $0 / 973$ \\
\hline Education level factors & $2 / 359$ & $0 / 000$ & $0 / 050$ & $0 / 986$ & $11 / 793$ & $0 / 028$ & $0 / 972$ \\
\hline Marketing factor & $2 / 935$ & $0 / 000$ & $0 / 055$ & $0 / 948$ & $24 / 67$ & $0 / 037$ & $0 / 949$ \\
\hline Environmental factor & $2 / 471$ & $0 / 000$ & $0 / 047$ & $0 / 969$ & $12 / 35$ & $0 / 031$ & $0 / 938$ \\
\hline Skill gap & $2 / 540$ & $0 / 000$ & $0 / 053$ & $0 / 953$ & $68 / 57$ & $0 / 036$ & $0 / 937$ \\
\hline
\end{tabular}

The Alpha Cronbach was used to determine the reliability of questionnaire. For this purpose, 30 questionnaires were distributed among managers and specialists of studied companies. The reliability of variables is represented in Table 2. Considering the coefficients higher than 0.7 for all variables, this indicates acceptable reliability of data collection tool.

Table 2: Alpha Cronbach coefficient (reliability of questionnaire)

\begin{tabular}{r|r|r|r|}
\hline N. & Name of variable & $\begin{array}{r}\text { Number of } \\
\text { questions }\end{array}$ & $\begin{array}{r}\text { Alpha Cronbach } \\
\text { coefficient }\end{array}$ \\
\hline 1 & Operational strategic factors & 8 & $0 / 895$ \\
\hline 2 & Education level factor & 5 & $0 / 878$ \\
\hline 3 & Marketing factor & 5 & $0 / 875$ \\
\hline 4 & Environmental factor & 5 & $0 / 827$ \\
\hline 5 & Skill gap in digital marketing & 9 & $0 / 906$ \\
\hline 6 & Questionnaire & 32 & $0 / 927$ \\
\hline
\end{tabular}

The data were analyzed using Spss 22 software to describe demographic information, assess normal distribution of sample, and determine the average of variables and Amos 21 software to test the hypotheses using structural equation modeling method. For this purpose, the structural model of research hypotheses was designed in Amos 21 software.

Based on correlation coefficient and multiple regression equations, the relationships between variables were measured. Then, the findings were analyzed according to results of testing research hypotheses by structural equation modeling method and their outputs including fitness indices and regression coefficients of structural model.

\section{FINDINGS}


DOI: 10.14807/ijmp.v8i1.507

\subsection{Demographic Findings}

The sample ( $\mathrm{n}=226)$ included 106 men (46.9\%) and 120 women (53.09\%). Also, most of the participants were in age range 31 to 40 years (38.9\%), had bachelor degree (70.4\%), and were employed as unit specialist (83.1\%).

\subsection{Data Normal Distribution Findings}

The results of Kolmogorov-Smirnov test which evaluated distribution normality of data are presented in Table 3.

Table 3: Results of Kolmogorov-Smirnov test

\begin{tabular}{|r|r|r|r|r|l|}
\hline Structure & $\begin{array}{r}\text { Number } \\
\text { of data }\end{array}$ & Mean & Value & (sig) level & Result \\
\hline Operational strategic factors & 226 & $3 / 181$ & 1.165 & 0.094 & $\begin{array}{l}\text { Normal } \\
\text { distribution }\end{array}$ \\
\hline Education level factor & 226 & $3 / 437$ & 1.256 & 0.084 & $\begin{array}{l}\text { Normal } \\
\text { distribution }\end{array}$ \\
\hline Marketing factor & 226 & $3 / 309$ & 0.867 & 0.179 & $\begin{array}{l}\text { Normal } \\
\text { distribution }\end{array}$ \\
\hline Skill gap in digital marketing & 226 & $3 / 642$ & 1.213 & 0.089 & $\begin{array}{l}\text { Normal } \\
\text { distribution }\end{array}$ \\
\hline
\end{tabular}

The results showed that since the significance level of test is above $0.05 \%$ and $Z$ value is less than 1.96 , the normality of data distribution is confirmed. The parametric tests and the maximum likelihood method may be used in structural equation modeling.

\subsection{The Results of Research Hypotheses}

The structural equation modeling was used to test the research hypotheses. For this purpose, the structural model of relationships among variables was designed using Amos 21 software. The designed structural model of sample was tested. In this regard, the questionnaires data was used in model. In the following, the final structural equation model of research is presented.

The overall fit indices obtained in hypotheses structural equation model are presented in Table 4. All of them have a good fit.

Table 4: Fit indicators of structural equation model

\begin{tabular}{|r|r|r|r|r|r|r|r|}
\hline $\begin{array}{r}\text { Structural } \\
\text { model }\end{array}$ & $\mathbf{X 2 / d f}$ & $\mathbf{P}$ & $\mathbf{R M S E A}$ & $\mathbf{C F I}$ & $\mathbf{C M I N}$ & $\mathbf{R M R}$ & $\mathbf{G F I}$ \\
\hline $\begin{array}{r}\text { Acceptable } \\
\text { level }\end{array}$ & $<3$ & $<0 / 05$ & $<0 / 07$ & $>0 / 9$ & --- & $<0 / 05$ & $>0 / 9$ \\
\hline $\begin{array}{r}\text { Structural } \\
\text { model }\end{array}$ & $2 / 796$ & $0 / 000$ & $0 / 052$ & $0 / 928$ & $427 / 24$ & $0 / 039$ & $0 / 931$ \\
\hline
\end{tabular}




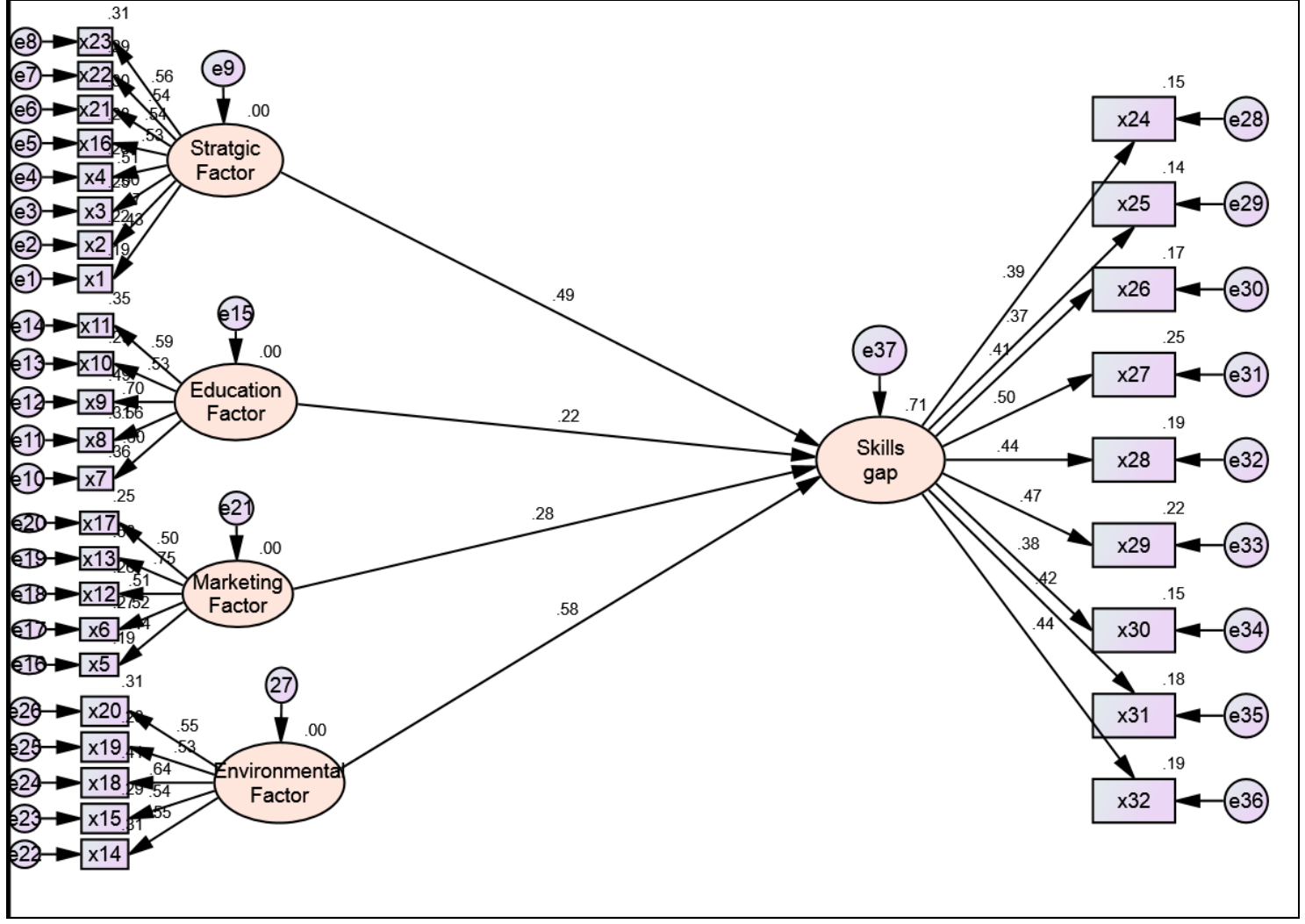

Figure 2: The coefficients obtained in calculation of structural equation

According to table 4, the overall fitness indicators of structural model for relationships among research variables are at an acceptable level. This indicates that the structural model has high fitness and validity to assess the relationship among variables. Given that the structural model of study was confirmed, the results of evaluating hypotheses using regression coefficient, critical values, and significance level are provided in Table 5.

Table 5: The evaluation of research hypotheses

\begin{tabular}{|l|c|c|c|l|}
\hline Result & $\begin{array}{l}\text { Critica } \\
\text { I value }\end{array}$ & $\begin{array}{l}\text { Sig. } \\
\text { level }\end{array}$ & $\begin{array}{l}\text { Regression } \\
\text { coefficient }\end{array}$ & Hypotheses \\
\hline $\begin{array}{l}\text { High direct, significant, } \\
\text { and positive effect }\end{array}$ & $5 / 504$ & $0 / 000$ & $0 / 494$ & $\begin{array}{l}\text { skill gap in <--- Operational strategic factors } \\
\text { digital marketing }\end{array}$ \\
\hline $\begin{array}{l}\text { Low direct, significant, } \\
\text { and positive effect }\end{array}$ & $3 / 843$ & $0 / 000$ & $0 / 219$ & $\begin{array}{l}\text { skill gap <--- Education level of customers } \\
\text { in digital marketing }\end{array}$ \\
\hline $\begin{array}{l}\text { Low direct, significant, } \\
\text { and positive effect }\end{array}$ & $4 / 240$ & $0 / 000$ & $0 / 278$ & $\begin{array}{l}\text { skill gap in digital <--- Marketing factors } \\
\text { marketing }\end{array}$ \\
\hline $\begin{array}{l}\text { High direct, significant, } \\
\text { and positive effect }\end{array}$ & $6 / 196$ & $0 / 000$ & $0 / 582$ & $\begin{array}{l}\text { skill gap in digital <--- Environmental factors } \\
\text { marketing }\end{array}$ \\
\hline
\end{tabular}

The results of testing first hypothesis (considering the regression coefficient (0.494) of relationship among variables) shows that the strategic operational factors play an important role in reducing and eliminating skill gap in digital marketing of communication companies. In other words, the strategic thinking in organization will 
INDEPENDENT JOURNAL OF MANAGEMENT \& PRODUCTION (IJM\&P)

http://www.ijmp.jor.br

v. 8, n. 1, January - March 2017

ISSN: 2236-269X

DOI: 10.14807/ijmp.v8i1.507

provide proper understanding of internal and external environment, suitable targeting for short and long-term, proper budgeting and allocation of corporate resources, and other strategic actions.

This will be a decisive factor in improving needed skills in digital marketing and will bridge the gap in this field. This result is consistent with findings of Royal and Lein (2014), Shing Guan and colleagues (2013), Smith (2010), and Sarfarazi and colleagues (2012).

The results of testing second hypothesis (considering the regression coefficient (0.219) of relationship among variables) showed that customer education level does not contribute much in reduction of skill gap in digital marketing. Rather, it seems that the presence of customers with higher academic levels and specific expertise highlights the skill gap in digital marketing of studied companies. Therefore, it is important that companies consider their target customers. This result is inconsistent with study of (JOHANSEN, 2011) and (ZAMANI; COLLEAGUES, 2011) in terms of opinion about customers.

The results obtained from testing third hypothesis (the role of marketing factors in reducing skill gap in digital marketing) considering its regression coefficient (0.278) shows almost similar situation to education level of customers. In other words, although the improved skill of using traditional marketing principles and its mix may somewhat impact on reduction of skill gap in digital marketing, the results of this study indicated that their role is not prominent in communication industry companies and they cannot bridge the gap in digital marketing. This argument is consistent with research results of (MORRIE, 2012; JAFARI et al., 2015; SADEGHI; GIVECHIAN, 2011).

The results of fourth hypothesis (the role of environmental factors in reducing the skill gap in digital marketing of communications industry companies) considering its regression coefficient (0.582) noted that the various environmental factors including cultural, social, political, legal, economic, technological, ideological, and etc factors have an important role in reducing the skill gap in digital marketing of these companies. Therefore, they should be considered in different conditions. This result is consistent with findings of (LONG et al., 2014; SEYED REZAI, 2014; ALAVI; ZEINALI , 2014). 


\section{DISSCUSION AND CONCLUSION}

The study of communication industry companies in terms of using digital marketing mechanisms in marketing and goods and services selling process showed that the companies had failures in different areas and this led to skill gap in goods and services digital marketing.

Some of the skill gap in companies and their employees include lack of communication skills in project management, low level of staff awareness about the business which lead to lack of strong relationships with customers, low level of customer interaction skills in company, lack of proper structure and necessary knowledge of customer relationship and proper interaction with customers management, lack of proper use of weblogs, online discussion forums and digital networks for exchanging information and predicting the future, lack of integrated strategy for future due to not using intelligent methods of marketing, lack of appropriate tools to measure and assess the needed skills for success in digital marketing, low needed technical knowledge such as website development, digital operating systems, and etc. to conduct successful marketing and bridge skill gap in digital marketing.

The identification of factors affecting the reduction of skill gap in digital marketing of studied companies will be crucial to improve digital marketing skills. This will provide better conditions for selling goods and services and more success. Considering the results, it seems that among the factors affecting the reduction of skill gap in digital marketing, the operational strategic and environmental factors are more effective. Therefore, the following suggestions are presented:

a) The implementation of operational strategic actions at all layers of company is one of the important factors which reduces skill gap in digital marketing. In this regard, the implementation of actions such as considering customer demands and dynamic understanding of target market, proper planning for digital marketing processes, allocation of funding for each stage of planning digital marketing, considering project management skills in marketing as one of the important factors affecting digital marketing, focusing on proper advertisement for company's products and services according to organizational values, participation 
of all organizational layers in digital marketing programs, setting the main objectives of marketing activities, attempt to achieve objectives with maximum efficiency, considering the current and future benefits of advertising costs in digital marketing, and etc. play an important role in reducing the skill gap in digital marketing and lead to company's success in products and services digital marketing.

b) Given the role of environmental factors as an effective indicator in reducing skill gap in digital marketing, some points in this context should be considered. First, the religion of people should certainly be considered in advertisements in virtual environment. Second, due to differences in business and trade in different cultures, this should be considered in e-commerce of companies, especially marketing. Third, the taxes, duties, divisions, and prohibition of some products or dealing with some countries should be considered in e-commerce, especially marketing. Fourth, the technological factors are one of the important factors which shorten products life and lead to constant innovation. Therefore, it should be considered in planning of company for advertisement. Finally, the domestic and foreign competition with companies having similar products and attitude towards e-marketing activities should be considered in planning of company.

c) Although this study tried to localize skill gap in digital marketing of communication industry companies and match them with organizational realities of companies in Iran, it seems that it is necessary to conduct a study which uses a more comprehensive approach to identify skill gap in digital marketing of companies in Iran. Therefore, it is suggested that future researchers provide a comprehensive model for needed skills in digital marketing of communications industry companies using qualitative approaches.

\section{REFERENCES}

AKAR, ERKAN; BIROL, TOPCU (2011). An examination of the factors influencing consumers' attitudes toward social media marketing. Journal of Internet Commerce, v. 10, n.1, p. 35-67.

BUZZARD, CHRISTOFER et al. (2011). The use of digital technologies in the classroom: A teaching and learning perspective. Journal of Marketing Education : 0273475311410845. 
CHAFFEY, D.; PATRON, M. (2012). From web analytics to digital marketing optimization :Increasing the commercial value of digital analytics. Journal of Direct, Data and Digital Marketing Practice, v. 14, n.1, p. 30-45.

DAY, G. S. (2011). Closing the marketing capabilities gap. Journal of Marketing, v. 75, p. 183-195.

DEISER, ROLAND; SYLVIAN NEWTON (2013). Six social-media skills every leader needs. McKinsey Quarterly.

HAMILL, J.; TAGG, S.; STEVENSON, A.; VESCOVI, T. (2010). Special edition New developments in online marketing. Journal of Marketing Management, v. 26, n. 3, p. 181-186.

JARVENIN, J.; TOLLINEN, A.; KARAJLOTOU, H.; Jayawardhena, C. (2012). Digital and social media marketing usage in N2N industrial section. Marketing Management Journal, v. 22, n.2, p.102-117.

JERZY, GROBELNY; RAFALł, MICHALSKI. (2015). The role of background color, inter letter spacing, and font size on preferences in the digital presentation of a product. Computers in Human Behavior, v. 43,p. 85-100.

MILLER, J.; GILANSSER, B. (2011). The "Inside" and the "Outside": Finding realities in interviews. In D. Silverman (Ed.), Qualitative Research. London: Sage.

MICHAELIDOU, N.; SIAMAGKA, N.; CHRISTODOULIDES, G. (2011). Usage, barriers and measurement of social media marketing: An exploratory investigation of small and Medium B2B brands. Industrial Marketing Management, v. 40,n. 7, p. 1153-1159.

QUINTON, S.; FENNEMORE, P. (2013). Missing a strategic marketing trick? The use of online social networks by UK charities. International Journal of Nonprofit and Voluntary Sector Marketing, v.18, p. 36-51.

ROYLE, J.; LAING, A. (2014). The digital marketing skill gap: Developing a Digital Marketer Modelfor the communication industries. International Journal of Information Management, v. 34, p. 65- 73.

SCHLEE, R.; HARICH, P. K. R. (2010). Knowledge and skill requirements for Marketing jobs in the 21st century. Journal of Marketing Education, v.32, n. 3,p. 341-352. 